\title{
Activated alveolar macrophages in subclinical pulmonary inflammation in collagen vascular diseases
}

\author{
BENOÎT WALLAERT, FRÉdÉRIC BART, COLETTE AERTS, ALI OUAISSI, \\ PIERRE YVES HATRON, ANDRÉ BERNARD TONNEL, CYR VOISIN
}

From the Département de Pneumologie, Hôpital A Calmette and Institut Pasteur; the Centre d'Immunologie et de Biologie Parasitaire, Institut Pasteur; and the Service de Médecine Interne Adultes, Hôpital Régional, Lille, France

ABSTRACT A study was initiated to determine whether alveolar macrophages from patients with $\bigcirc$ collagen vascular diseases but free of pulmonary symptoms were spontaneously activated and $\rightarrow$ whether they released various mediators related to the pathogenesis of pulmonary fibrosis. Alveolar macrophages obtained by bronchoalveolar lavage from 32 patients with proved collagen vascular disease but no evidence of lung disease were compared with those from 10 patients with collagen $₹$ vascular disease with interstitial lung disease (CVD-ILD) and from 10 healthy controls. The total $\vec{\oplus}$ number of alveolar macrophages did not differ between patients with collagen vascular disease and $\infty$ controls but were substantially increased in the CVD-ILD group. Alveolar macrophages from 31 of 0 the 32 patients with collagen vascular disease and from all 10 in the CVD-ILD group had at least one $\sum^{\circ}$ criterion of activation. Neutrophil chemotactic activity was detected in supernatants from alveolar macrophage culture in 23 of the 32 patients with collagen vascular disease and from nine of the 10 in $\%$

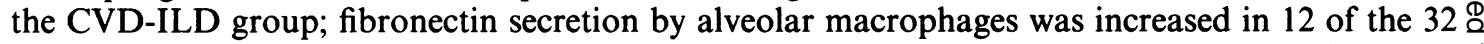
patients with collagen vascular disease and in nine of the 10 in the CVD-ILD group. Furthermore, $\overrightarrow{\overrightarrow{0}}$ alveolar macrophages from 20 of the 32 patients with collagen vascular disease and four of the 103 CVD-ILD patients spontaneously released increased amounts of superoxide anion. Thus alveolar macrophages were spontaneously activated in a high proportion of patients with collagen vascular disease.

Collagen vascular diseases are frequently associated with interstitial pulmonary fibrosis. ' Since interstitial fibrosis is generally an irreversible process, an understanding of the mechanisms leading to fibrosis is necessary for the development of treatment strategies to prevent irreversible alveolar damage. Current concepts of the pathogenesis of pulmonary fibrosis emphasise the role of alveolitis. The accumulation of inflammatory cells in the alveolus is believed to mediate in injury and the process of fibrosis.

Bronchoalveolar lavage allows a simple determination of effector cell populations and their state of activation in the alveolitis. The alveolitis associated with interstitial pulmonary fibrosis associated with

Address for reprint requests: Dr Benoît Wallaert, Département de Pneumologie, Hôpital A Calmette, Bld J Leclercq, 59037 Lille Cédex, France.

Accepted 17 September 1987 collagen vascular disease is characterised by the $\frac{3}{3}$ presence of both neutrophils and alveolar macro- $\delta$ phages. ${ }^{2}$ There is evidence that alveolar macrophages $₹$ are activated and spontaneously secrete mediators $ᄋ$ concerned in the pathogenesis of pulmonary fibrosis, and that in addition they direct the activity of various other cells that play a part. ${ }^{3-5}$ Recent reports have shown that an inflammatory alveolitis may be present 0 in symptomless patients with collagen vascular N disease. $^{6-11}$ We recently showed that alveolitis was ${ }_{\omega}^{N}$ present in a high proportion of patients with collageno vascular disease who had no clinical or radiologicalo evidence of pulmonary disease. ${ }^{9}$ The distribution of immune and inflammatory cells in the lower respira- $\stackrel{\infty}{+}$ tory tract of these patients was similar to that reported 0 in patients with interstitial pulmonary fibrosis asso-

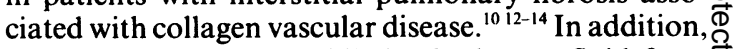
the presence of neutrophils in the lavage fluid from $\mathbb{\Phi}$ untreated patients was associated with a progressive $\frac{}{\sigma}$ deterioration of their pulmonary function. ${ }^{9}$ Together 
these data are consistent with the hypothesis that alveolitis precedes changes in lung connective tissue,,$^{211-15}$ and that early detection of alveolitis might predict which patients are at risk of developing clinically apparent disease.

A study was initiated to determine whether alveolar macrophages from patients with collagen vascular disease who had no overt pulmonary disease spontaneously released products relevant to the pathogenesis of pulmonary fibrosis. Comparisons were made with cells from patients with collagen vascular disease and associated interstitial lung disease (CVD-ILD) and from healthy controls.

\section{Methods}

\section{SUBJECTS}

We studied 32 patients with proved collagen vascular disease. Thirty were female and all were non-smokers with ages ranging from 21 to 65 (mean 36.7) years. The diagnosis of collagen vascular disease was made on the basis of well established criteria for primary Sjögren's syndrome $(\mathrm{n}=9)$, progressive systemic sclerosis $(n=12)$, rheumatoid arthritis $(n=5)$, dermatopolymyositis $(n=3)$, and mixed connective tissue disease $(n=3) .^{16-20}$ None had symptoms or signs suggesting that the collagen vascular disease had affected the respiratory tract, and all had normal chest radiographs as judged by two radiologists who were unaware of the clinical data. None had a history of occupational or drug exposure known to be associated with interstitial lung disease. A history of pulmonary disease and clinical or chest radiograph abnormalities were exclusion criteria. The results of pulmonary function measurements (mean (SEM)\%) were: total lung capacity (TLC) 96 (4.6) predicted, forced vital capacity (FVC) 97 (4.2) predicted, forced expiratory volume in one second $\left(\mathrm{FEV}_{1}\right), 105(4 \cdot 3)$ predicted, and diffusing capacity for carbon monoxide (transfer factor, TLCO) $109(6 \cdot 1)$.

The control groups consisted of 10 healthy nonsmokers and 10 non-smoking patients with CVD-ILD ( 8 progressive systemic fibrosis, 1 rheumatoid arthritis, 1 dermatopolymyositis). The interstitial lung disorder was defined by clinical, physiological, radiological and histological criteria. ${ }^{121}$

\section{BRONCHOALVEOLAR LAVAGE}

Bronchoalveolar lavage was performed, after premedication with atropine and under local anaesthesia with lignocaine, with a wedged fibreoptic bronchoscope (Olympus model BF-B3, Olympus Corporation of America, New York). A total of 250 $\mathrm{ml}$ of sterile normal saline was instilled in five $50 \mathrm{ml}$ aliquots with immediate gentle vacuum aspiration after each aliquot. ${ }^{20}$ Total and differential cell counts were determined and the viability of the alveolar macrophages was assessed by trypan blue exclusion. Bronchoalveolar lavage fluid was filtered through several layers of sterile surgical gauze and centrifuged at $400 \mathrm{~g}$ for 10 minutes at $4^{\circ} \mathrm{C}$. After three washings the pellet was resuspended at a cell concentration of $1.5 \times$ $10^{6} / \mathrm{ml}$ in Hanks' balanced salt solution (HBSS). Informed consent was obtained from all subjects.

\section{ALVEOLAR MACROPHAGE ISOLATION}

Two millilitre volumes of the cell suspension were cultured at $37^{\circ} \mathrm{C}$ in humidified air $(5 \%$ carbon dioxide) in $35 \mathrm{~mm}$ diameter plastic culture dishes. After two hours' incubation non-adherent cells were removed. According to differential cell counts of adherent cells stained by Wright's technique there were at least $95 \%$ alveolar macrophages and no basophils or mast cells. ${ }^{22}$ Viability at the end of the incubation period was over $95 \%$. Serum free RPMI-1640 (3 ml) was then added to each culture and incubation was continued for three hours in the same conditions as before.

Supernatants from cultures were collected and filtered $(0.2 \mu \mathrm{mol} / 1$ filter Gelman Sciences Inc, Ann Arbor, Michigan) and stored at $-30^{\circ} \mathrm{C}$ until they were assayed. All supernatants were assayed within two weeks of being harvested.

\section{NEUTROPHIL CHEMOTACTIC ACTIVITY ASSAY}

Neutrophil chemotactic activity derived from alveolar macrophages was measured by counting the number of neutrophils that passed through a $3 \mu \mathrm{m}$ micropore filter (Nucleopore Corporation, Pleasanton, California) from the upper component of a 48 well microchemotaxis chamber (Neuro Probe, Cabin John, Maryland) in response to the macrophage supernatant in the lower chamber. ${ }^{23}$ To distinguish chemokinesis from chemotaxis supernatants on both sides of the filter membrane were studied. There was no difference from the negative controls (buffer), which indicated a chemotactic process in the experimental wells. The number of neutrophils that had migrated through the filter was determined microscopically under oil immersion. Four fields were read in each well and each supernatant was studied in quadruplicate. The results were expressed as the difference between the mean number of cells per field in the experimental well and the mean number of cells per field in the control well (migration toward medium). As a positive control, migration towards FMLP $0 \cdot 1 \mu \mathrm{mol} / 1$ (Peninsula Laboratories Inc, San Carlos, California) was determined.

\section{FIBRONECTIN ASSAY}

Fibronectin was determined by radioimmunoassay. ${ }^{24}$ The results were expressed as ng fibronectin $/ 10^{6}$ cells per hour. 


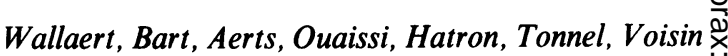

SUPEROXIDE ANION ASSAY

Spontaneous generation of superoxide anion was assayed by a lucigenin dependent chemiluminescence method adapted from Williams and Cole, ${ }^{2526}$ in which lucigenin (bis- $N$-methylacridinium nitrate; Sigma Chemical Co, St Louis, Missouri) served as a chemilumigenic probe. Lucigenin $10^{4} \mathrm{M}$ was dissolved in HBSS buffered with $18 \mathrm{mmol} / 1$ HEPES $(N-2-$ hydroxyethyl-piperazine- $N$-2-ethane sulfonic acid). Alveolar cells were centrifuged at $800 \mathrm{~g}\left(10 \mathrm{~min}, 4^{\circ} \mathrm{C}\right)$ and resuspended in HBSS-HEPES to a concentration of $1 \times 10^{6}$ viable alveolar macrophages $/ \mathrm{ml}$. The suspension was kept on ice in a siliconised glass container until use. Chemiluminescence was measured at $37^{\circ} \mathrm{C}$ using a Luminometer (Lumac System AG, Basel). A $500 \mu$ l aliquot of the alveolar macrophage suspension was added to each phial; each phial contained a $900 \mu$ laliquot of the lucigenin solution and a $50 \mu \mathrm{l}$ aliquot of a $3 \%$ gelatin solution. A $100 \mu \mathrm{l}$ aliquot from a $120 \mu \mathrm{g} / \mathrm{ml}$ superoxide dismutase solution was added to one phial. The total volume in each phial was brought to $1.650 \mathrm{ml}$ by adding the appropriate amount of HBSS-HEPES. All the phials were incubated in parallel. Intensity of luminescence was integrated for 60 seconds after a 12 minute incubation $\left(37^{\circ} \mathrm{C}\right)$. The chemiluminescence response were determined by subtracting background chemiluminescence values from the mean recorded chemiluminescence. The results are expressed in relative luminescence units $(\mathrm{RLU}) / 0.5 \times 10^{6}$ viable alveolar macrophages.
STATISTICAL ANALYSIS

Most of the data were non-parametric and compari- $\frac{9}{0}$ sons were made by means of the Mann-Whitney U $\frac{\mathrm{C}}{0}$ test.

\section{Results}

NUMBER AND TYPE OF BRONCHOALVEOLAR CELLS $\overrightarrow{0}$ The volume of bronchoalveolar lavage fluid recovered was not significantly different between patients and $\vec{\sigma}$ controls $(\mathrm{p}>0.04)$. The CVD-ILD group had significantly greater cell counts than patients with: collagen vascular disease alone (collagen vascular $\omega$ disease group) or controls (table 1). The percentage of $\vec{\sim}$ alveolar macrophages was significantly less in the $\triangle$ CVD and in CVD-ILD groups than in controls, 을 though absolute numbers of alveolar macrophages did not differ between CVD and control groups (table 1). An increased total count and proportion of lym-? phocytes and neutrophils were found in the collagen vascular disease and CVD-ILD groups. This was largely because 12 of the collagen vascular disease $\infty$ patients and four of the CVD-ILD group hade increased proportions of lymphocytes $(>18 \%)$-ranging from $18 \%$ to $59 \%$ of the recovered cells. The proportion of neutrophils in the lavage fluid was increased $(>4 \%)$ in 14 of the collagen vascular disease and in seven of the CVD-ILD group. Overall, bron- $\stackrel{\Phi}{\Omega}$ choalveolar lavage fluid studies in collagen vascular $\overrightarrow{\vec{\partial}}$ diseases showed that 13 of the collagen vascular

Bronchoalveolar lavage cells from patients with collagen vascular disease without pulmonary disease (CVD), from patients with collagen vascular diseases and interstitial lung disorders (CVD-ILD), and from controls

\begin{tabular}{|c|c|c|c|c|c|c|c|c|c|c|}
\hline & \multirow[b]{2}{*}{$n$} & \multirow{2}{*}{$\begin{array}{l}\text { Total cell } \\
\text { count } \\
\left(10^{4} / \mathrm{ml}\right)\end{array}$} & \multicolumn{2}{|c|}{ Alveolar macrophages } & \multicolumn{2}{|c|}{ Lymphocytes } & \multicolumn{2}{|c|}{ Neutrophils } & \multicolumn{2}{|c|}{ Eosinophils } \\
\hline & & & $(\%)$ & $\left(10^{4} / \mathrm{ml}\right)$ & $(\%)$ & $\left(10^{4} / \mathrm{ml}\right)$ & $(\%)$ & $\left(10^{4} / \mathrm{ml}\right)$ & $(\%)$ & $\left(10^{4} / \mathrm{ml}\right)$ \\
\hline CVD & 32 & $\begin{array}{l}14 \cdot 5 \\
(5 \cdot 4-48)\end{array}$ & $\begin{array}{l}78 \cdot 3^{*} \\
(38-97)\end{array}$ & $\begin{array}{l}10 \cdot 8 \\
(4 \cdot 8-38)\end{array}$ & $\begin{array}{l}17 \cdot 6^{*} \\
(2-59)\end{array}$ & $\begin{array}{l}2 \cdot 87^{*} \\
(0 \cdot 16-17)\end{array}$ & $\begin{array}{l}3 \cdot 56^{*} \\
(0-12)\end{array}$ & $\begin{array}{l}0 \cdot 64^{*} \\
(0-4 \cdot 2)\end{array}$ & $\begin{array}{l}0 \cdot 4 \\
(0-5)\end{array}$ & $\begin{array}{l}0.08 \\
(0-0.76)\end{array}$ \\
\hline \multicolumn{11}{|l|}{$\begin{array}{l}\text { Primary } \\
\text { Siögren }\end{array}$} \\
\hline syndrome & 9 & $\begin{array}{l}13 \cdot 7 \\
(5 \cdot 5-35)\end{array}$ & $\begin{array}{l}68 \cdot 8 \\
(38-88)\end{array}$ & $\begin{array}{l}8 \cdot 3 \\
(4 \cdot 8-13 \cdot 9)\end{array}$ & $\begin{array}{l}27 \cdot 2 \\
(4-59)\end{array}$ & $\begin{array}{l}4 \cdot 7 \\
(0 \cdot 2-17 \cdot 5)\end{array}$ & $\begin{array}{l}3.55 \\
(0-12)\end{array}$ & $\begin{array}{l}0 \cdot 64 \\
(0-4 \cdot 2)\end{array}$ & $\begin{array}{l}0.33 \\
(0-1)\end{array}$ & $\begin{array}{l}0.04 \\
(0-0 \cdot 16)\end{array}$ \\
\hline \multicolumn{11}{|l|}{ Progressive } \\
\hline sclerosis & 12 & $\begin{array}{l}14 \cdot 2 \\
(5 \cdot 4-34 \cdot 2)\end{array}$ & $\begin{array}{l}82 \cdot 7 \\
(68-96)\end{array}$ & $\begin{array}{l}11 \cdot 7 \\
(4 \cdot 8-31 \cdot 1)\end{array}$ & $\begin{array}{l}12 \cdot 8 \\
(2-25)\end{array}$ & $\begin{array}{l}1 \cdot 8 \\
(0 \cdot 22-4 \cdot 8)\end{array}$ & $\begin{array}{l}3 \cdot 9 \\
(0-9)\end{array}$ & $\begin{array}{l}0.55 \\
(0-2 \cdot 4)\end{array}$ & $\begin{array}{l}0 \cdot 33 \\
(0-2)\end{array}$ & $\begin{array}{l}0 \cdot 1 \\
(0-0 \cdot 76)\end{array}$ \\
\hline $\begin{array}{l}\text { Rheumatold } \\
\text { arthritis }\end{array}$ & 5 & $\begin{array}{l}13 \cdot 7 \\
(7 \cdot 3-20)\end{array}$ & $\begin{array}{l}78 \cdot 4 \\
(64-97)\end{array}$ & $\begin{array}{l}10 \cdot 4 \\
(5 \cdot 1-14)\end{array}$ & $\begin{array}{l}18 \cdot 4 \\
(2-31)\end{array}$ & $\begin{array}{l}2 \cdot 75 \\
(0 \cdot 16-6 \cdot 2)\end{array}$ & $\begin{array}{l}3 \cdot 2 \\
(1-5)\end{array}$ & $\begin{array}{l}0.47 \\
(0.08-1)\end{array}$ & $\begin{array}{l}0 \\
(0)\end{array}$ & $\begin{array}{l}0 \\
(0)\end{array}$ \\
\hline $\begin{array}{l}\text { Dermato- } \\
\text { polymyositis }\end{array}$ & 3 & $\begin{array}{l}22 \cdot 3 \\
(6-48)\end{array}$ & $\begin{array}{l}88 \\
(80-93)\end{array}$ & $\begin{array}{l}18 \cdot 6 \\
(5 \cdot 5-38 \cdot 4)\end{array}$ & $\begin{array}{c}9 \\
(4-14)\end{array}$ & $\begin{array}{l}2 \cdot 6 \\
(0.52-6 \cdot 7)\end{array}$ & $\begin{array}{l}2 \cdot 7 \\
(0-5)\end{array}$ & $\begin{array}{l}0 \cdot 9 \\
(0-2 \cdot 4)\end{array}$ & $\begin{array}{l}0 \cdot 33 \\
(0-1)\end{array}$ & $\begin{array}{l}0.16 \\
(0-0.48)\end{array}$ \\
\hline \multicolumn{11}{|l|}{$\begin{array}{l}\text { Mixed } \\
\text { connective }\end{array}$} \\
\hline tissue disease & 3 & $\begin{array}{l}15 \cdot 6 \\
(15-17)\end{array}$ & $\begin{array}{l}73 \cdot 3 \\
(68-79)\end{array}$ & $\begin{array}{l}11 \cdot 5 \\
(10 \cdot 2-12 \cdot 4)\end{array}$ & $\begin{array}{l}20 \\
(14-24)\end{array}$ & $\begin{array}{l}3 \cdot 1 \\
(2 \cdot 1-3 \cdot 7)\end{array}$ & $\begin{array}{l}5 \\
(3-7)\end{array}$ & $\begin{array}{l}0.78 \\
(0.4-1.05)\end{array}$ & $\begin{array}{l}1 \cdot 6 \\
(0-5)\end{array}$ & $\begin{array}{l}0.25 \\
(0-0.75)\end{array}$ \\
\hline CVD-ILD & 10 & $\begin{array}{l}34 \cdot 6^{*} \\
(7 \cdot 3-80)\end{array}$ & $\begin{array}{l}76 \cdot 6^{*} \\
(41-94)\end{array}$ & $\begin{array}{l}26 \cdot 7^{*} \\
(6 \cdot 6-44)\end{array}$ & $\begin{array}{l}13 \cdot 7^{*} \\
(4-52)\end{array}$ & $\begin{array}{l}3 \cdot 6^{*} \\
(0.9-15)\end{array}$ & $\begin{array}{l}7 \cdot 2 * \\
(0-18)\end{array}$ & $\begin{array}{l}3 \cdot 16^{*} \\
(0-0 \cdot 13)\end{array}$ & $\begin{array}{l}2 \cdot 5^{*} \\
(0-7)\end{array}$ & $\begin{array}{l}1 \cdot 05^{*} \\
(0-4 \cdot 2)\end{array}$ \\
\hline Controls & 10 & $\begin{array}{l}9 \cdot 86 \\
(2 \cdot 9-21)\end{array}$ & $\begin{array}{l}91 \cdot 2 \\
(87-98)\end{array}$ & $\begin{array}{l}9 \cdot 1 \\
(2 \cdot 8-18)\end{array}$ & $\begin{array}{c}7 \cdot 7 \\
(2-14)\end{array}$ & $\begin{array}{l}0 \cdot 83 \\
(0 \cdot 2-2 \cdot 5)\end{array}$ & $\begin{array}{l}0.7 \\
(0-2)\end{array}$ & $\begin{array}{l}0.05 \\
(0-0.14)\end{array}$ & $\begin{array}{l}0 \cdot 4 \\
(0-1)\end{array}$ & $\begin{array}{l}0.03 \\
(0-0.1)\end{array}$ \\
\hline
\end{tabular}

Values expressed as mean (range).

*Difference from control is statistically significant $(\mathrm{p}<0.05)$ 
disease group had normal bronchoalveolar lavage fluid, five had pure lymphocyte alveolitis, and 14 had a neutrophil alveolitis (with associated alveolar lymphocytosis in seven).

\section{ALVEOLAR MACROPHAGE FUNCTION}

Spontaneous release of neutrophil chemotactic activity by alveolar macrophages was detected in 23 of the 32 patients in the CVD group (fig 1). All but one of the patients with increased proportions of neutrophils

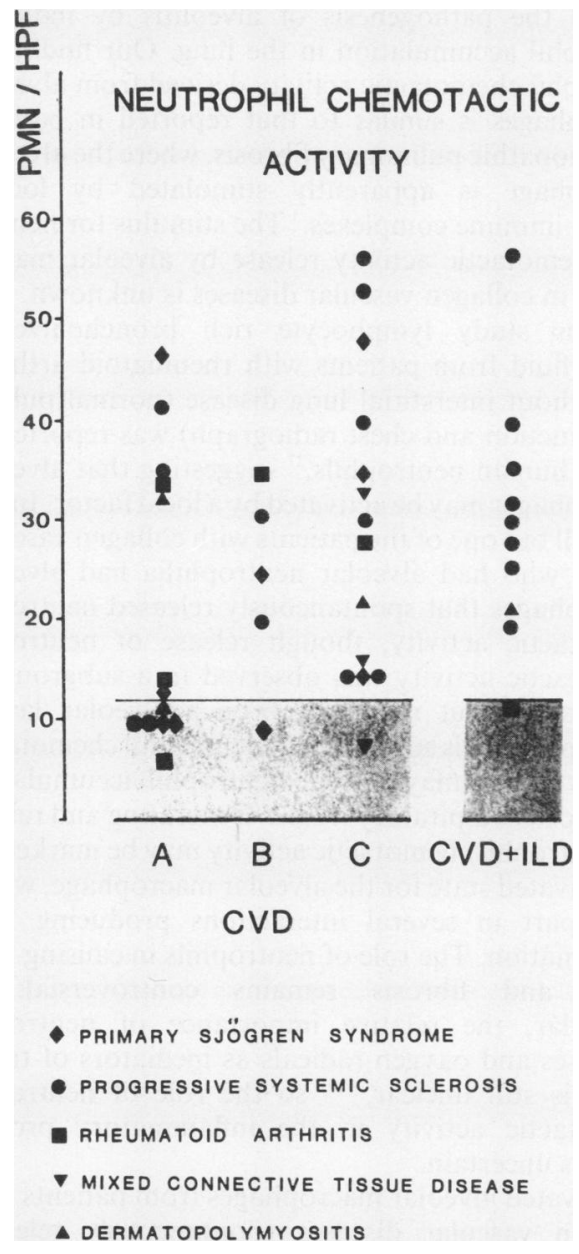

Fig 1 Spontaneous neutrophil chemotactic activity (NCA) generation by alveolar macrophages from patients with collagen vascular disease (CVD) but without lung disease: $A$-denotes patients with normal bronchoalveolar lavage differential; $B$ - patients with alveolar lymphocytosis $(>2 \times$ $10^{4}$ lymphocytes $(\mathrm{ml}) ; C$-patients with alveolar neutrophilia $\left(>0.1 \times 10^{4}\right.$ neutrophils $\left./ \mathrm{ml}\right)$ with or without increased percentage of lymphocytes, and from patients with collagen vascular disease and associated interstitial lung disease $(C V D+I L D)$. The hatched area indicates normal values obtained from healthy non-smokers. had alveolar macrophages that spontaneously released neutrophil chemotactic activity. The release of neutrophil chemotactic activity also occurred in 10 patients without neutrophil alveolitis. There was no significant relationship between the percentage or total number of neutrophils in bronchoalveolar lavage fluid and the generation of neutrophil chemotactic activity by alveolar macrophages. Of the CVD-ILD patients, nine had increased neutrophil chemotactic activity in their supernatants.

Alveolar macrophages from 12 patients in the CVD group released substantial amounts of fibronectin (fig 2 ), compared with nine of 10 CVD-ILD patients. None of the healthy controls had evidence of fibronectin release. Fibronectin was spontaneously released by alveolar macrophages irrespective of the nature of the alveolitis - that is, of whether they had a neutrophil, lymphocyte, or normal cell pattern in their broncho-

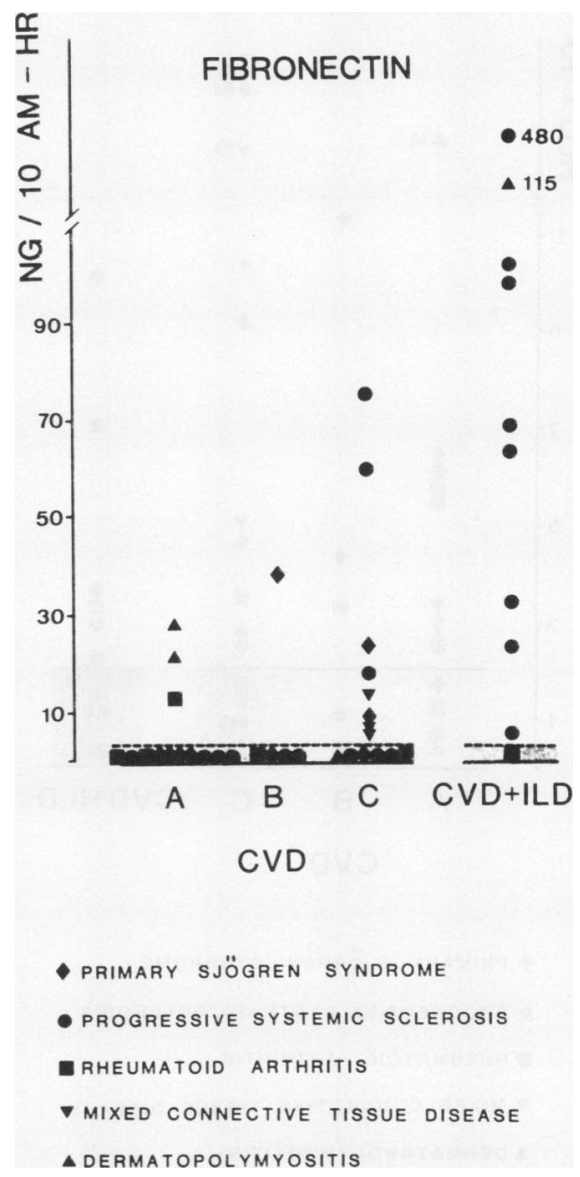

Fig 2 Spontaneous fibronectin secretion of alveolar macrophages from patients with collagen vascular disease (CVD) but without lung disease. Key as in figure 1. 
alveolar lavage fluid. Alveolar macrophages from 10 of 12 patients in the CVD group that spontaneously released fibronectin also released neutrophil chemotactic activity.

Superoxide anion was spontaneously released by alveolar macrophages from 21 patients in the CVD group (fig 3 ) and by six in the CVD-ILD group. The pattern of alveolar inflammation did not affect the release of superoxide by alveolar macrophages.

There was no correlation between the level of the three alveolar macrophage activation markers and the total number of alveolar macrophages.

\section{Discussion}

Our data clearly show that alveolar macrophages from patients with collagen vascular disease but no lung

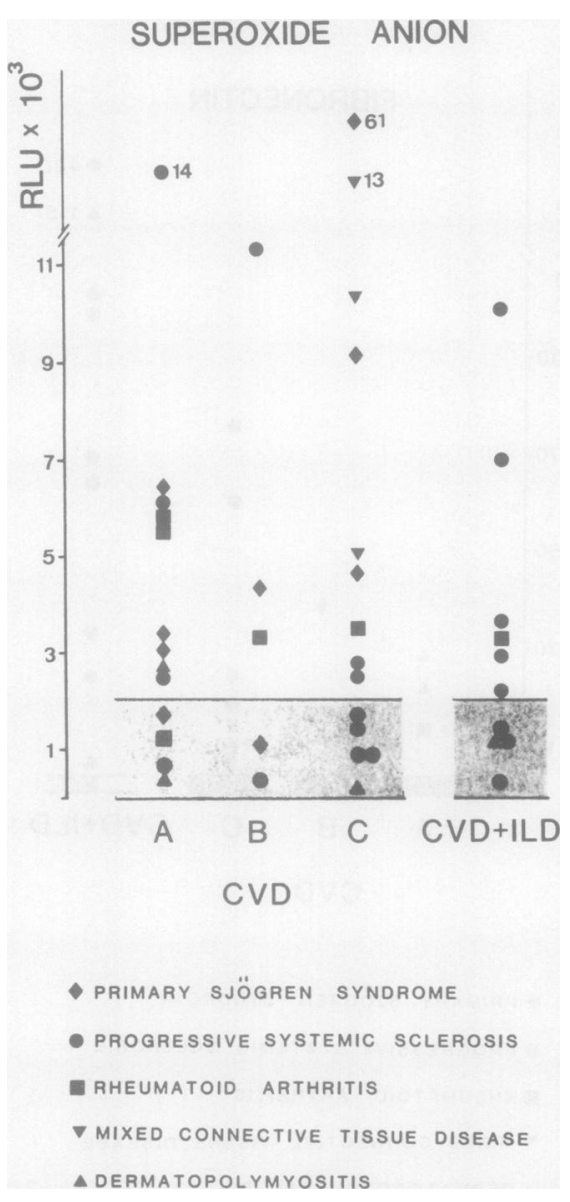

Fig 3 Spontaneous superoxide anion release by alveolar macrophages from patients with collagen vascular disease (CVD) but without lung disease. Key as in figure 1.

Wallaert, Bart, Aerts, Ouaissi, Hatron, Tonnel, Voisin $\underset{x}{\stackrel{0}{\otimes}}$

disease are spontaneously activated and release $\vec{F}$ various inflammatory mediators. The pattern of $\stackrel{\infty}{?}$ alveolar inflammation, in terms of the type of cells recovered from the lower respiratory tract and their $\frac{\bar{\sigma}}{\bar{D}}$ state of activation, did not differ among patients with $\frac{\widehat{\sigma}}{\overrightarrow{0}}$ collagen vascular diseases between those who had $\varrho$ overt lung manifestations and those who did not.

In this study three effector functions of alveolar $\vec{\circ}$ macrophages were evaluated. The release of neutro- phil chemotactic activity is thought to play a crucial $\vec{\omega}$ part in the pathogenesis of alveolitis by inducing neutrophil accumulation in the lung. Our finding of $\vec{x}$ neutrophil chemotactic activity derived from alveolar $\vec{\omega}$ macrophages is similar to that reported in patients $\overrightarrow{-}$ with idiopathic pulmonary fibrosis, where the alveolar $\underset{A}{\sim}$ macrophage is apparently stimulated by locally formed immune complexes. ${ }^{3}$ The stimulus for neutrophil chemotactic activity release by alveolar macro- $c$ phages in collagen vascular diseases is unknown. In a previous study lymphocyte rich bronchoalveolar lavage fluid from patients with rheumatoid arthritis but without interstitial lung disease (normal pulmo- $\vec{\oplus}$ nary function and chest radiograph) was reported to attract human neutrophils, ${ }^{27}$ suggesting that alveolar 0 macrophages may be activated by a local factor. In our $\sum^{\circ}$ study all but one of the patients with collagen vascular disease who had alveolar neutrophilia had alveolar macrophages that spontaneously released neutrophil $\mathbb{Q}$ chemotactic activity, though release of neutrophil $\underset{7}{\rightleftharpoons}$ chemotactic activity was observed in a subgroup of $\frac{0}{3}$ patients without increased bronchoalveolar lavage $\frac{3}{\sqrt{3}}$ neutrophils. This suggests that neutrophil chemotactic activity release may precede neutrophil accumulation of the lower respiratory tract." Generating and releasing neutrophil chemotactic activity may be markers of the activated state for the alveolar macrophage, which takes part in several interactions producing lung 3 . inflammation. The role of neutrophils in causing lung $\delta$ injury and fibrosis remains controversial; in $\frac{3}{3}$ particular, the relative importance of neutrophil proteases and oxygen radicals as mediators of tissue injury is still unclear, ${ }^{28-30}$ so the role of neutrophilo chemotactic activity in the inflammatory process remains uncertain.

Activated alveolar macrophages from patients with $N$ collagen vascular diseases spontaneously released $N$ increased amounts of fibronectin, which may have $\mathrm{a}_{\sigma}^{\omega}$ role in the interaction between macrophages and fibroblasts, since macrophages appear to have the capacity both to stimulate and to suppress fibro- $\stackrel{\mathbb{N}}{\sim}$ blasts. ${ }^{31}{ }^{32}$ Fibronectin, a large glycoprotein, is known $?$ to mediate cell matrix interaction through various $-{ }^{-}$ functions, including its chemotactic properties and as $\overrightarrow{\mathbb{D}}$ a competence factor for fibroblast growth. Increased $\frac{\rho}{\mathbb{Q}}$ production of fibronectin by alveolar macrophages is $a$ common feature of several interstitial lung diseases, 
implying that increased production of this macromolecule may be a general response of the alveolar macrophage to various stimuli. ${ }^{4}$ In our study all but one patient with collagen vascular disease associated with interstitial lung disease showed increased spontaneous release of fibronectin. In contrast, only a subgroup of those with collagen vascular disease alone had alveolar macrophages that spontaneously released increased amounts of fibronectin. The fibronectin produced by the human alveolar macrophage can act as a chemoattractant for lung fibroblasts and might contribute to the development of fibrosis. Since these patients had normal chest radiographs and normal pulmonary function, close follow up is required to determine whether they are at risk of developing symptomatic interstitial lung disease in the future.

Spontaneous superoxide release by alveolar macrophages as assessed by chemiluminescence was noted in a high proportion of patients with collagen vascular diseases. This may reflect increased metabolic activity of the phagocytes in collagen vascular diseases. There is evidence suggesting that increased superoxide generation reflects active pulmonary inflammation. ${ }^{33-36}$ The mechanisms responsible for alveolar macrophage activation in the lower respiratory tract of patients with collagen vascular diseases is unknown. Possibly they are activated primarily as a consequence of an immune process or as a non-specific inflammatory response at a distance from an inflammatory site. ${ }^{3738}$

We have shown that subclinical alveolar inflammation, comprising activated alveolar macrophages and lymphocytes or neutrophils (or both), is present in a high proportion of patients with collagen vascular diseases. The spontaneous generation of superoxide anion and of neutrophil chemotactic activity may reflect the activated state of alveolar macrophages, whereas the spontaneous release of fibronectin may be important in the pathogenesis of interstitial lung disease. Our results suggest that fibronectin release increases but superoxide anion generation decreases as interstitial lung disease develops in patients with collagen vascular disease. The presence of asymptomatic alveolitis in collagen vascular diseases does not imply that these patients will develop overt pulmonary fibrosis in the future. Since interstitial lung disease is frequently associated with collagen vascular diseases, this group presents a unique opportunity to characterise changes in the alveoli that may precede the permanent damage to lung parenchyma. A detailed follow up of such patients is required to determine the relationship of our findings to the development of interstitial lung disease.

We thank Mrs C Fourneau for her expert technical assistance and enthusiastic support and Mrs C Zeiske for her kind secretarial assistance. We extend a special thanks to Drs Jean Marie Grosbois and Didier Gosset for their referrals of patients. This work was supported in part by a grant from the Fonds Special des Comités Départementaux Contre les Maladies Respiratoires et la Tuberculose (Contract 85-G/18), by INSERM (Réseau de Recherche Clinique, Participation des Cellules Inflammatoires en Pathologie Respiratoire) and by the University of Lille II.

\section{References}

1 Hunninghake GW, Fauci AS. Pulmonary involvement in the collagen vascular diseases. Am Rev Respir Dis 1979;119:471-503.

2 Crystal RG, Bitterman PB, Rennard SI, Hance AJ, Keogh BA. Interstitial lung diseases of unknown cause. Disorders characterized by chronic inflammation of the lower respiratory tract. $N$ Engl J Med 1984;310: 154-66, 235-44.

3 Hunninghake GW, Gadek JE, Lawley TJ, Crystal RG. Mechanisms of neutrophil accumulation in the lung of patients with idiopathic pulmonary fibrosis. $J$ Clin Invest 1981;68:259-69.

4 Rennard SI, Hunninghake GW, Bitterman PB, Crystal RG. Production of fibronectin by the human alveolar macrophage: mechanism for the recruitment of fibroblasts to sites of tissue injury in interstitial lung diseases. Proc Natl Acad Sci USA 1981;78:7147-51.

5 Bitterman PB, Adelberg S, Crystal RG. Mechanisms of pulmonary fibrosis: spontaneous release of the alveolar macrophage-derived growth factor in the interstitial lung disorders. $J$ Clin Invest 1983;72:1801-13.

6 Solal-Celigny $\mathrm{P}$, Laviolette $\mathrm{M}$, Hebert J, Cormier Y. Immune reactions in the lungs of asymptomatic dairy farmers. Am Rev Respir Dis 1982;126:964-7.

7 Wallaert B, Colombel JF, Tonnel AB, Bonniere PH, Cortot A, Paris JC, Voisin C. Evidence of lymphocyte alveolitis in Crohn's disease. Chest 1985;87:363-7.

8 Gellert AR, Macey MG, Uthayakumar S, Newland AC, Rudd RM. Lymphocyte subpopulations in bronchoalveolar lavage fluid in asbestos workers. $A m R e v$ Respir Dis 1985;132:824-8.

9 Wallaert B, Hatron PY, Grosbois JM, Tonnel AB, Devulder B, Voisin C. Subclinical pulmonary involvement in collagen-vascular diseases assessed by bronchoalveolar lavage. Relationship between alveolitis and subsequent changes in lung function. $\mathrm{Am}$ Rev Respir Dis 1986;133:574-80.

10 Garcia JGN, Parhami N, Killam D, Garcia PL, Keogh BA. Bronchoalveolar lavage fluid evaluation in rheumatoid arthritis. Am Rev Respir Dis 1986;133: 450-4.

11 Bitterman PB, Rennard SI, Keogh BA, Wewers MD, Adelberg S, Crystal RG. Familial idiopathic pulmonary fibrosis. Evidence of lung inflammation in unaffected family members. $N$ Engl J Med 1986;314: 1343-7.

12 Rossi GA, Bitterman PB, Rennard SI, Ferrans VJ, Crystal RG. Evidence for chronic inflammation as a component of the interstitial lung disease associated 
with progressive systemic sclerosis. Am Rev Respir Dis 1985;131:612-7.

13 Owens GR, Paradis IL, Gryzan S, Medsger TA, Follansbee WP, Klein HA, Dauber JH. Role of inflammation in the lung disease of systemic sclerosis: comparison with idiopathic pulmonary fibrosis. $J$ Lab Clin Med (USA) 1986;107:253-60.

14 Pesci A, Bertorelli G, Manganelli P, Ambanelli U. Bronchoalveolar lavage analysis of interstitial lung disease in CREST syndrome. Clin Exp Rheumatol 1986;4:121-4.

15 Keogh BA, Crystal RG. Aleolitis: the key to the interstitial lung disorders. Thorax 1982;37:1-10.

16 Moutsopoulos HM. Sjögren's syndrome (sicca syndrome): current issues. Ann Intern Med 1980;92: 212-26.

17 Subcommittee for scleroderma. Criteria of the American Rheumatism Association Diagnostic and Therapeutic. Criteria Committee: preliminary criteria for the classification of systemic sclerosis (scleroderma). Arthr Rheum 1980;23:581-90.

18 Ryckewaert A. Polyarthrite rhumatoîde. In: Kahn MF, Peltier AP, eds. Maladies dites systémiques. 2nd ed. Paris: Flammarion, 1986:135-68.

19 Serratrice G, Schiano A. Dermatopolymyosites. In: Kahn MF, Peltier AP, eds. Maladies dites systémiques. 2nd ed. Paris: Flammarion, 1986:324-58.

20 Scharp GC, Irwin WS, Tan EM, Gould RG, Homman HR. Mixed connective tissue disease an apparently distinct rheumatic disease syndrome associated with a specific antibody to an extractable antigen (ENA). $\mathrm{Am}$ J Med 1972;52:148-53.

21 Crystal RG, Fulmer JD, Roberts WC, Moss ML, Line BR, Reynolds HY. Idiopathic pulmonary fibrosis: clinical, histologic, radiographic, physiologic, scintigraphic, cytologic, and biochemical aspects. Ann Intern Med 1976;85:769-88.

22 Joseph M, Tonnel AB, Torpier G, Capron A, Arnoux B, Benveniste $J$. Involvement of immunoglobulin $\mathrm{E}$ in the secretory processes of alveolar macrophages from asthmatic patients. J Clin Invest 1983;71:221-8.

23 Gosset PH, Tonnel AB, Joseph M, Prin L, Mallart A, Charon J, Capron A. Secretion of a chemotactic factor for neutrophils and eosinophils by alveolar macrophages from asthmatic patients. $J$ Allergy Clin Immunol 1984;74:827-34.

24 Ouaissi MA, Neyrinck JL, Capron A. Development of a competitive radioimmunoassay for human plasma fibronectin. Int Arch Allergy Appl Immunol 1986;81: 75-80.

25 Williams AJ, Cole PJ. Investigation of alveolar macro- phage function using lucigenin dependent chemiluminescence. Thorax 1981;36:866-9.

26 Aerts C, Wallaert B, Grosbois JM, Voisin C. Superoxide anion release by alveolar macrophages in pulmonary $\overline{\bar{\sigma}}$ sarcoidosis. Ann NY Acad Sci 1986;465:193-200.

27 Garcia JG, Perlman MB, Garcia PL, Keogh BA. Effects $\mathbb{Q}$ of BAL fluid on neutrophil function in rheumatoid arthritis. Chest 1986;89 (suppl):151-3.

28 Snider GL. Interstitial pulmonary fibrosis-which cell is $\overrightarrow{0}$ the culprit? Am Rev Respir Dis 1983;127:535-9.

29 Johnson KJ, Fantone JC III, Kaplan J, Ward PA. In vitro $\vec{\omega}$ damage of rat lungs by oxygen metabolites. J Clin Invest 1981;67:983-93.

30 Thrall RS, Phan SH, McCormick JR, Ward PA. The development of bleomycin-induced pulmonary fibrosis $\omega$ in neutrophil depleted and complement-depleted rats. Am J Pathol 1981;105:76-81.

31 Lugano EM, Dauber JH, Elias JA, Bashey RI, Jimanez음 SA, Danielle RP. The regulation of lung fibroblast proliferation by alveolar macrophages in experimental silicosis. Am Rev Respir Dis 1984;129:767-71.

32 Elias JA, Rossman MD, Zurier RB, Danielle RP. Human alveolar macrophage inhibition of lung fibroblast growth. A prostaglandin-dependent process. Am Reve Respir Dis 1985;131:94-9.

33 Nakagawara A, Desantis NM, Nogueira N, Nathan CF. Lymphokines enhance the capacity of human mon-O ocytes to secrete reactive oxygen intermediates. $J$ Clin Invest 1982;70:1042-8.

34 Sugimoto M, Nakashima $H$, Ando M, Fukushima $K$, ֻ Araki S. Immunoglobulin G-induced Superoxide production by alveolar macrophages obtained from $\Rightarrow$ smokers and nonsmokers [abstract]. Am Rev Respir Dis 1985;131:196A.

35 Gerberick GF, Willoughby JB, Willoughby WF. Serum factor requirement for reactive oxygen intermediate release by rabbit alveolar macrophages. J Exp Med亏 1985;161:392-9.

36 Gerberick GF, Jaffe HA, Willoughby JB, Willoughby WF. Relationships between pulmonary inflammation, plasma transsudation and oxygen metabolite secretion by alveolar macrophages. J Immunol 1986;137:114-21. ْ

37 Giroud JP, Yao JS, Pelletier M, Florentin I, Bird J. Acute 3 non specific inflammation and modification of macro-o phage and lymphocyte functions. $\mathrm{Br} J$ Dermato $P$ 1983;109:41-54.

38 Bird J, Pelletier M, Tissot M, Giroud JP. The modification of the oxidative metabolism of cells derived bothN locally and at distance from the site of an acute inflammatory reaction. J Leukocyte Biol 1985;37: N 109-20. 